The British Official Film in South-East Asia 
Ian Aitken

\section{The British Official Film in South-East Asia}

Malaya/Malaysia, Singapore and Hong Kong 
Ian Aitken

Hong Kong Baptist University

Kowloon Tong, Hong Kong

ISBN 978-1-137-49343-9

ISBN 978-1-137-49344-6 (eBook)

DOI $10.1057 / 978-1-137-49344-6$

Library of Congress Control Number: 2016956646

(C) The Editor(s) (if applicable) and The Author(s) 2016

The author(s) has/have asserted their right(s) to be identified as the author(s) of this work in accordance with the Copyright, Designs and Patents Act 1988.

This work is subject to copyright. All rights are solely and exclusively licensed by the Publisher, whether the whole or part of the material is concerned, specifically the rights of translation, reprinting, reuse of illustrations, recitation, broadcasting, reproduction on microfilms or in any other physical way, and transmission or information storage and retrieval, electronic adaptation, computer software, or by similar or dissimilar methodology now known or hereafter developed.

The use of general descriptive names, registered names, trademarks, service marks, etc. in this publication does not imply, even in the absence of a specific statement, that such names are exempt from the relevant protective laws and regulations and therefore free for general use. The publisher, the authors and the editors are safe to assume that the advice and information in this book are believed to be true and accurate at the date of publication. Neither the publisher nor the authors or the editors give a warranty, express or implied, with respect to the material contained herein or for any errors or omissions that may have been made.

Cover illustration: (C) IWM (DM 149)

Printed on acid-free paper

This Palgrave Macmillan imprint is published by Springer Nature

The registered company is Macmillan Publishers Ltd.

The registered company address is: The Campus, 4 Crinan Street, London, N1 9XW, United Kingdom 


\section{Preface}

The research project which finds a major output in this book began in 2008, when I received my first Hong Kong government research grant. The project began with a study of the official film in Hong Kong, and perhaps the major achievement of that part of the project was the discovery of a virtually unknown film unit: the Hong Kong Film Unit (HKFU) (1959-72). To this day, I do not fully understand how such an official film unit, albeit small, could disappear into obscurity to the extent that it did, particularly when it was situated relatively closely in terms of geography and time-period to a film unit that still remains very well known: the Malayan Film Unit (MFU) (1946-57). The HKFU, clearly now needs to be considered alongside the other major British and Dominions film units and organisations. As this research project developed, a website was also constructed to house the many primary research documents collected over a period of eight years. Writing now, in April 2016, it is hoped that this website will soon be able to host some of the films made by the HKFU, thus making these films - finally - widely available to the academic community, and thereby increasing the visibility of the film unit.

The main content of the website, is, however, not related to Hong Kong. As this research project developed it began to take on a clear trajectory, that of studying the dispersal and diffusion of the British official film into British South-East Asia during the post-war period. The foremost content of the website, therefore, relates to this, and consists of thousands of pages of documents written by officials and film-makers in London, Hong Kong, Singapore, and Malaya/Malaysia between 1945 and 1975. These documents have been placed on-line within the website, and great 
appreciation must be afforded to the National Archives at Kew for granting permission for me to upload the documents onto the website for ten years, a period of time which began in 2015. These documents, consisting of policy documents, official reports and correspondence between officials, film-makers and others, tell the story of the development of the British official film in Hong Kong, Singapore and Malaya/Malaysia over the period in question: a volatile and critical period which encompassed the founding of the People's Republic of China (PRC); pro-communist riots in Hong Kong; the civil war between the PRC and Kuomintang, based in Taiwan; the outbreak of the Korean, Indo-China and Vietnam wars; the Malayan Emergency; the decolonisation of Malaya and Singapore; and expulsion of Singapore from Malaysia. Behind all of that, however, and as these primary documents attest, was the epochal background of the Cold War. Many of these documents concern what was sometimes referred to as the 'world-wide Soviet conspiracy'; the struggle against communism in South-East Asia; and the promotion of democracy and, increasingly importantly, the Commonwealth of Nations.

A number of major players also leap from the pages of these documents, including the First Commissioner-General for South-East Asia, Malcolm MacDonald; the head of the Foreign Office Information Research Department, Ralph Murray; the head of the Commonwealth Relations Office, Ben Cockram; the head of the Malayan Film Unit, Tom Hodge; and the head of Government Information Services (GIS) in Hong Kong, John Lawrence Murray. Beyond these were also many other officials, filmmakers and film producers who are referred to in the pages of this book. These documents also reveal the developing role of the three British 'overseas offices' over the period: the Foreign Office (FO), Colonial Office $(\mathrm{CO})$ and Commonwealth Relations Office (CRO); and also the tensions which sometimes arose between officials within these organisations; particularly during the decline of the CO during the late 1960s. Beyond this, British information agencies were also active in the region, and these are also discussed in the pages of this book. They include the Public Relations Office and GIS of Hong Kong; British Information Services in Malaya/ Malaysia and Singapore; United Kingdom Information Offices in Malaya/ Malaysia and Singapore; and the British Council in Malaya/Malaysia, Singapore and Hong Kong. There were also, as previously mentioned, two official film units in the region: the MFU and HKFU. In addition to these, however, three other film organisations are also frequently mentioned in the pages of this book: the Crown Film Unit, the Colonial Film 
Unit, and the Cathay Film Services organisation; whilst the Central Office of Information (COI) in London also appears as a major player. In addition to all of this, occasional references are also made to the Shell Film Unit, based in Singapore.

What should become apparent from all of the above is how complex and complicated the overall situation was here, involving many individuals and organisations both in the region and in the metropole. The story that emerges from this is, therefore, equally complicated, and structuring that story from the jigsaw puzzle of primary evidence was a work of detectivelike labour. That labour was also made all the more difficult by the fact that there are many gaps in the evidence because primary documents either went missing or were deliberately destroyed. Major gaps in the evidential record consist of the following: crucial material relating to the role of GIS and the HKFU during the period of pro-communist riots in Hong Kong, material which has clearly been deliberately removed; material relating to the development of television in Malaya/Malaysia over 1962-5; material relating to the role of the British Council in Singapore and Malaya/ Malaysia over 1960-70; and material relating to the use of particular official films. The latter is a major problem, as, for reasons that still remain unclear, there are very few references to particular films amongst the large number sent into the region by the COI over the period.

In addition to the above issue of problems with the record, several other issues emerged during the course of this research. First, looking at three different territories and comparing them from different perspectives involved an inevitable degree of reiteration. So, for example, looking at these territories in relation to film units, individuals, situations and organisations sometimes meant that these reappear across the various chapters of this book. Although I have attempted to manage and minimise the recurrence involved here, some is, nonetheless, inevitable. The lateral approach adopted here has, however, and whatever its drawbacks, also proved to be profitable, as it has enabled the myriad interconnections which took place at the time to be set out. Second, the story that unfolds from scrutiny of these primary documents is a rather close, empirical one. This follows from the nature of the documents, which are largely concerned with specific interchanges between officials regarding operational, technical and administrative matters. The documents rarely spell out or address matters touching on overarching historical, let alone theoretical matters. In order to resolve this issue, I have commented on the larger historical context in each chapter. In addition to that, however, I have also provided 
the chapters of this book with a lengthy foundational introduction which touches on a number of critical and theoretical issues related to the British official film. In particular, the introduction separates films into what I call 'forms': general categories of the official film; from the 'Griersonian' form to the 'post-colonial' (not postcolonial) form. This categorisation has also allowed me to address some recent debates which have arisen on the character and importance of the post-war British official and sponsored film.

Ian Aitken Hong Kong April 2016 


\section{ACKNOWLEDgments}

My first thanks must go to the four full-time research assistants who have helped me at various times during the course of this research project. They are, in order of appointment, and beginning in 2008, Yvonne Young, Venus Lam, Seth Henderson and Teresa Ho. Throughout the course of this research project they have all shown diligence and imagination in collecting primary materials under my guidance, and I am indebted to them all. I would also like to thank staff at the various archives at which this research was carried out: the United Kingdom National Archives at Kew, the National Archives of Singapore and the Hong Kong Records Office. This research project was also informed by three conferences which I hosted at Hong Kong Baptist University in 2009, 2012 and 2013: (1) 'Hong Kong Documentary Film, the Regional Context and Theoretical Perspectives'; (2) 'Public Service Film-making in Hong Kong, the Hong Kong Film Unit and RTHK, and the Influence of the Griersonian and British Colonial Official Film on the Region and Beyond' (2012); and (3) 'The Documentary Film in South and South-East Asia Conference' (2013). These conferences became a forum for discussion on the colonial official film, and, given that, I would like thank the following for presentations which had an influence on this book: Tom Rice, Brian Winston, Michael Ingham, Tim Barnard, Peter Bloom, Camille Deprez, Jane Landman, Rosaleen Smyth, Scott Anthony, Deane Williams, Hassan Abdul Muthalib, and others.

I would also like to acknowledge the following funding awards: 
HKBU School of Communication, for conference support for the three conferences referred to above (IAS 12-13/06, and IAS 11-12/01); and also IAS 12-13/03, for the 'Documentary Film Research Programme'; and IAS 11-12/02, for 'Documentary Film in Hong Kong'.

HKBU FRG1/15-16/028: British official information and film activity in Malaya and Singapore 1957-65, the development of television, and evolution of the Malayan Film Unit

HKBU FRG2/14-15/078: An analysis of primary data relating to British official information and film activity in Malaysia, Singapore and Hong Kong during the 1960s, focusing on the role played by the United Kingdom Information Services, British Information Services and the British Council

HKBU FRG1/14-15/049: British official information and film activity in Malaysia, Singapore and Hong Kong during the 1960s: The Role of United Kingdom Information Services, British Information Services and the British Council.

HKBU FRG1/13-14/044: A Study of the 1960 Singaporean Official Film Series Berita Singapura.

RGC GRF 24111: The Colonial Film Units of Hong Kong, Singapore and Malaysia, and the Influence of British Official Film-making.

RGC GRF 240213: A Study of the 1960s Singaporean Official Film Series Berita Singapura. 


\section{Contents}

1 The Forms of the British Official/Sponsored Documentary Film

2 Diverging Jurisdictions: The Influence of 'Griersonian' and 'Civil Service' Traditions of Official Film-making on the Malayan Film Unit (1946-57) and Hong Kong Film Unit (1959-73)

3 Delusions of Regional Superintendence at the End of Empire and the Case of the Singapore Regional Information Office, 1947-61

4 The Use of the Official Film in Malaya/Malaysia, Singapore and Hong Kong, 1957-1973, and the Role of the United Kingdom Information Services, British Information Services, British Council and Hong Kong Government Information Services (with Ka Yee Teresa Ho)

5 Berita Singapura (1963-9) and Hong Kong Today (1967-73) 
xii CONTENTS

6 The Rise of Television, Persistence of Authoritarianism, and Decline of the Official Film in Singapore, Malaya/ Malaysia and Hong Kong, 1955-75

Bibliography

Index 